Daria Korytkowska*

\title{
STATYSTYCZNA EWIDENCJA SPRAW O ODSZKODOWANIA Z TYTUŁU ODPOWIEDZIALNOŚCI CYWILNEJ PODMIOTÓW LECZNICZYCH W POLSCE
}

\section{Wprowadzenie}

System ochrony zdrowia wraz z jego otoczeniem stanowi zbiór różnych elementów (m.in. takich jak: struktury rządowe, samorządowe, zasoby medyczne, pacjenci) ${ }^{1}$, których głównym zadaniem jest prowadzenie wszelkich zorganizowanych działań związanych z zapobieganiem, utrzymywaniem i polepszaniem stanu zdrowia człowieka ${ }^{2}$. Zadanie to jest niezwykle trudne do zrealizowania, gdyż wymaga współpracy pomiędzy trzema najważniejszymi podmiotami tego systemu: świadczeniobiorcami (pacjentami), świadczeniodawcami (lekarzami, podmiotami leczniczymi) oraz płatnikiem (Narodowym Funduszem Zdrowia). Ze względu na swój bezpośredni charakter szczególne znaczenie będzie miała relacja pomiędzy świadczeniodawcą a świadczeniobiorcą. Jest ona bowiem związana z ryzykiem, które może wywołać różne skutki, w postaci np. utraty zdrowia lub życia pacjenta, a co za tym idzie powstania odpowiedzialności po stronie szkodzącego.

Celem niniejszego artykułu jest dokonanie krótkiego przeglądu różnego rodzaju reżimów odpowiedzialności, jakim podlegają świadczeniodawcy usług medycznych, następnie zaś przedstawienie skali roszczeń o charakterze majątkowym w stosunku do świadczeniodawców, którzy wyrządzili szkodę pacjentom.

Zastosowano metodę badawczą polegającą na analizie danych pochodzących ze statystyk Ministerstwa Sprawiedliwości oraz publikowanych przez Rzecznika Praw Pacjenta sprawozdań rocznych. Artykuł napisano na podstawie literatury i obserwacji

* Uniwersytet Łódzki, Wydział Ekonomiczno-Socjologiczny.

1 M. Kolwitz, Polski system ochrony zdrowia - perspektywy i możliwości zastosowania systemów ochrony zdrowia innych państw Unii Europejskiej, "Annales Academiae Medicae Stetinesis, Roczniki pomorskiej Akademii Medycznej w Szczecinie" 2010, nr 56, s. 131-146.

2 I. Rudawska, Opieka zdrowotna - aspekty rynkowe i marketingowe, Warszawa 2007, PWE, s. 15. 
akt dotyczących spraw o odszkodowanie za szkody wyrządzone przez służbę zdrowia z okręgu łódzkiego.

\section{Miejsce odpowiedzialności cywilnej w świetle innych reżimów odpowiedzialności}

Pojęcie odpowiedzialności może być rozumiane w różny sposób. Według M. Paszkowskiej jest to możność lub gotowość ponoszenia konsekwencji wzięcia na siebie zarówno dobrych, jak i złych skutków własnego postępowania ${ }^{3}$, natomiast L. Nowakowski definiuje odpowiedzialność jako obowiązek ponoszenia przewidzianych przez przepisy prawa lub inne normy społeczne konsekwencji zachowania się własnego lub innych osób.

W wypadku podmiotów leczniczych odpowiedzialność ta może być różna: karna, cywilna, pracownicza czy też zawodowa.

Odpowiedzialność karna dotyczy czynów zabronionych, które nazywane są przestępstwami lub wykroczeniami. Pierwszy rodzaj dotyczy takich czynów człowieka, które według Kodeksu karnego są traktowane jako zbrodnia lub występek, bezprawny, zawiniony i szkodliwy społecznie w stopniu wyższym niż znikomy. Natomiast za wykroczenia, zgodnie z Kodeksem wykroczeń, uznawane są czyny społecznie szkodliwe, zabronione przez ustawę, która obowiązywała w czasie ich popełniania4.

Odpowiedzialność cywilna natomiast dotyczy wszelkich relacji społecznych o charakterze majątkowym, które wywołują skutki finansowe zarówno po stronie poszkodowanego, jak i sprawcy szkody ${ }^{5}$. Powszechnie nazywa się ją odpowiedzialnością dłużnika za wyrządzoną szkodę majątkową czy też niemajątkową w postaci naruszenia takich dóbr osobistych jak: życie, zdrowie, wolność, dobre imię czy kult osoby zmarłej ${ }^{6}$.

Odpowiedzialność zawodowa w odróżnieniu od karnej nie jest wymierzana przez państwo, ale przez funkcjonujący w danej strukturze medycznej sąd etyczny.

3 M. Paszkowska, Zarzadzanie podmiotami leczniczymi. Aspekty prawne, Wydawnictwo AMELIA Aneta Siewiorek, Rzeszów 2014.

4 P. Szczerba, Odpowiedzialnośc karna lekarzy, w: A. Fiutak, T. Podleśny, M. Kozik, P. Szczerba, K. Zblewska-Wrońska, Odpowiedzialność prawna pracowników medycznych. Przepisy, Przykłady, Orzecznictwo. C.H. Beck, Warszawa 2013.

5 M. Filar, O odpowiedzialności lekarzy i zakładów opieki zdrowotnej w ogólności, w: M. Filar, S. Krześ, E. Marszałkowska-Krześ, P. Zaborowski, Odpowiedzialność lekarzy i zakładów opieki zdrowotnej, LexisNexis, Warszawa 2004, s. 15.

6 A. Fiutak, Odpowiedzialność cywilna lekarzy, w: A. Fiutak i in., op.cit. 
W wypadku środowiska lekarskiego realizowana jest ona za pośrednictwem sądów lekarskich, które orzekają o naruszeniu przez członków korporacji reguł deontologicznych zawartych w Kodeksie Etyki Lekarskiej ${ }^{7}$.

Odpowiedzialność pracownicza zaś dotyczy czynów, które wynikają między innymi z Kodeksu Pracy oraz relacji łączącej danego lekarza z pracodawcąa ${ }^{8}$.

$\mathrm{W}$ wypadku różnych podmiotów leczniczych może nastąpić kumulacja różnych rodzajów odpowiedzialności. Sytuacja taka uzależniona jest między innymi od tego, jaką osobowość prawną posiada dany podmiot. Gdy mamy do czynienia z osobami fizycznymi, czyli np. lekarzami pracującymi na własny rachunek, może nastąpić kumulacja zarówno odpowiedzialności cywilnej i karnej, jak również odpowiedzialności zawodowej i pracowniczej. Natomiast w wypadku podmiotów posiadających osobowość prawną, np. samodzielne publiczne zakłady opieki zdrowotnej, kumulacja ta ogranicza się tylko do odpowiedzialności cywilnej oraz ewentualnej odpowiedzialności podmiotów zbiorowych.

Odpowiedzialność podmiotów zbiorowych, jak podaje M. Filar, jest w swojej istocie odpowiedzialnością zbliżoną do odpowiedzialności karnej, którą podmiot zbiorowy ponosiłby niezależnie od odpowiedzialności karnej osób fizycznych działających w jego imieniu lub strukturze. W ramach tej odpowiedzialności system kar ogranicza się do zastosowania kary pieniężnej uzależnionej od osiągniętych przychodów danej placówki oraz różnego rodzaju zakazów9

Od 2012 r. dla podmiotów leczniczych wykonujących działalność w rodzaju świadczenia szpitalnego ustanowiono nowy reżim odpowiedzialności, mający charakter pozasądowy. Jest to odpowiedzialność za tzw. zdarzenia medyczne, która jest rozpatrywana przed specjalnie powołanymi w tym celu Komisjami Wojewódzkimi do spraw orzekania o zdarzeniach medycznych. $Z$ założenia odpowiedzialność ta miała stanowić alternatywę dla cywilnego postępowania sądowego, dlatego też tej metodzie można również przypisać charakter odpowiedzialności majątkowej. Jednak w tym wypadku odpowiedzialność ta jest z góry ograniczona. Artykuł 67k pkt 7 ustawy o prawach pacjenta i Rzeczniku Praw Pacjenta ${ }^{10}$ stanowi bowiem, iż poszkodowany może żąać w razie doznania uszczerbku na zdrowiu kwoty odszkodowania nie większej niż 100 tys. PLN, a w wypadku śmierci poszkodowanego jego następcy prawni mogą ubiegać się o odszkodowanie w kwocie nie większej niż 300 tys. PLN. Zaletą tego postępowania ma być też czas rozpatrzenia sprawy, przewidywany na okres nie dłuższy niż 4 miesiące.

\footnotetext{
7 M. Filar, op.cit., s. 16.

8 Ibidem, s. 17.

9 Ibidem, s. 236.

${ }^{10}$ Ustawa o prawach pacjenta i Rzeczniku Praw Pacjenta, Dz. U. 2009, nr 52, poz. 417 z późn. zm.
} 
Dla uściślenia przedstawmy (w myśl art. 4 ustawy o działalności leczniczej z dnia 15 lipca 2011 r.) jednostki stanowiące podmiot leczniczy:

1) przedsiębiorcy działający $w$ ramach wszelkich form prawnych przewidzianych dla wykonywania działalności gospodarczej, poza sytuacjami, kiedy ustawa stanowi inaczej, którymi są m.in.:

a. osoby fizyczne,

b. spółki osobowe, takie jak: spółka cywilna, jawna, partnerska, komandytowa, komandytowo-akcyjna,

c. spółki kapitałowe, takie jak spółka z ograniczoną odpowiedzialnością, spółka akcyjna,

d. spółdzielnie,

e. inne formy prawne,

2) samodzielne publiczne zakłady opieki zdrowotnej,

3) jednostki budżetowe,

4) instytuty badawcze,

5) fundacje i stowarzyszenia, których celem statutowym jest wykonywanie zadań w zakresie ochrony zdrowia i których statut dopuszcza prowadzenie działalności leczniczej,

6) osoby prawne i jednostki organizacyjne działające na podstawie przepisów o stosunku Państwa do Kościoła katolickiego w Rzeczypospolitej Polskiej, o stosunku Państwa do innych Kościołów i związków wyznaniowych oraz o gwarancjach wolności sumienia i wyznania - w zakresie, w jakim wykonują działalność leczniczą.

Jak można zauważyć, $\mathrm{z}$ punktu widzenia ekonomicznego największe znaczenie będzie miała odpowiedzialność cywilna oraz odpowiedzialność za zdarzenia medyczne, z którymi związane są sankcje finansowe wymierzane w postaci tzw. odszkodowania lub zadośćuczynienia. Pierwsza z wymienionych form jest świadczeniem, które ma pozwolić na naprawienie szkody majątkowej poprzez przywrócenie stanu poprzedniego lub wypłatę odpowiedniego świadczenia pieniężnego (art. 363 Kodeksu cywilnego). Świadczenie to występuje w dwóch postaciach - w postaci jednorazowego świadczenia stanowiącego zwrot kosztów, jakie wyniknęły z uszkodzenia ciała lub rozstroju zdrowia albo $\mathrm{w}$ postaci wielokrotnego świadczenia wypłacanego $\mathrm{w}$ formie renty. Zadośćuczynienie natomiast jest świadczeniem, które ma na celu kompensację doznanej szkody niemajątkowej zwanej krzywdą ${ }^{11} \mathrm{i}$ jest wypłacane jednorazowo.

${ }_{11}$ T. Młynarski, Zadośćuczynienie pieniężne za doznana krzywdę jako świadczenie o charakterze jednorazowym, „Monitor Ubezpieczeniowy” 2012, nr 51, s. 38-43. 
Z punktu widzenia natomiast wysokości zasądzanych świadczeń niewątpliwie postępowanie przed sądem cywilnym może okazać się korzystniejsze dla skarżącego. Jest to podyktowane tym, iż w porównaniu do Komisji Wojewódzkiej do spraw orzekania o zdarzeniach medycznych, roszczenia pacjentów wpływające do sądu nie mają ograniczeń, dlatego z roku na rok obserwuje się wzrost wysokości dochodzonych przez nich świadczeń.

\section{Ewidencja spraw o odszkodowania za szkody wyrządzone przez służbę zdrowia rejestrowana przez sądy powszechne}

Ewidencja spraw o odszkodowania za szkody wyrządzone przez służbę zdrowia prowadzona przez sądy powszechne oraz ewidencja spraw wpływających do Wojewódzkich Komisji do spraw orzekania o zdarzeniach medycznych stanowią istotne źródło informacji o szkodach wywołanych przez pracowników ochrony zdrowia. Nie istnieje bowiem żaden inny oficjalny system raportowania o występowaniu szkód pacjenta czy też system raportowania o wystąpieniu tzw. zdarzeń niepożądanych. Takie systemy oczywiście w Polskiej ochronie zdrowia zaczynają powstawać, jednakże mają one charakter niejawny. Przykładami takich systemów raportowania funkcjonujących w Polsce mogą być1 ${ }^{12}$ :

- $\quad$ system stworzony na potrzeby akredytacji jednostek działalności leczniczej, którym zarządza Centrum Monitorowania Jakością z siedzibą w Krakowie,

- dobrowolny system stworzony przez Uniwersytet Medyczny w Łodzi o nazwie Bezpieczna Opieka Podstawowa,

- obowiązkowy system dotyczący rejestracji reakcji na działanie leków,

- dobrowolny system raportowania zdarzeń niepożądanych, zaprojektowany i wdrożony w Samodzielnym Publicznym Szpitalu Klinicznym nr 1 w Lublinie ${ }^{13}$. Niestety, publikowana przez podmioty publiczne statystyka w ocenie autorki obarczona jest wieloma czynnikami, które zniekształcają rzeczywistą skalę zjawiska występowania szkód medycznych gdyż:

- dotyczy ona tylko i wyłącznie spraw, które wpłynęły do sądu - wiele spraw nie jest zgłaszanych, chociażby ze względu na stosunkowo wysokie koszty postępowania

12 D. Korytkowska, System raportowania niepożądanych zdarzeń jako instrument zarządzania ryzykiem w jednostkach prowadzacych działalność lecznicza, w: Rynek ubezpieczeń. Współczesne problemy, red. W. Sułkowska, Difin, Warszawa 2013, s. 60-73.

${ }^{13}$ S. Ostrowski, M. Mikos, System raportowania zdarzeń niepożądanych - model lubelski, „Ogólnopolski Przegląd Medyczny” 2007, nr 5, s. 60-61. 
(koszt wniesienia pozwu odpowiadający 5\% wartości przedmiotu sporu oraz inne koszty, np. wydanie opinii biegłych, koszty administracyjne ${ }^{14}$ itp.), brak wiedzy poszkodowanych na temat swoich praw, świadomość poszkodowanych co do przewlekłości postępowań sądowych - przykładowo średni czas rozpatrywania sprawy w latach 2012-2013 przez sąd cywilny według raportu przygotowanego przez zespół J. Budzowskiej wynosił 39 miesięcy itp.),

- wpływ spraw zawiera $\mathrm{w}$ sobie również te sprawy, które $\mathrm{z}$ różnych przyczyn zostały ponownie wpisane do repertorium - a zatem wpływ sprawy dotyczący tego samego przedmiotu i tych samych podmiotów jest na przykład dwa razy ewidencjonowany,

- nie ujawnia, ile wypadków szkód na pacjentach miało miejsce w danym roku, gdyż dotyczy tylko i wyłącznie liczby wyroków, jakie zapadły w danym roku kalendarzowym - a te mogą dotyczyć różnych okresów, w których doszło do wystąpienia szkody.

Niemniej jednak, jak już wspomniano, jest to jedyne źródło informacji o szkodach wywołanych różnymi przewinieniami, których przykładowy katalog przedstawia M. Nesterowicz, wymieniając m.in. ${ }^{15}$ :

- brak wymaganej zgody pacjenta na działania lecznicze,

- przekroczenie zakresu zgody danej przez pacjenta,

- niepoinformowanie pacjenta o ryzyku i ewentualnych możliwych negatywnych skutkach zabiegu lekarskiego,

- odmowa udzielenia pomocy przez lekarza,

- zwłoka lub zaniechanie dokonania zabiegu,

- dokonanie zabiegu bez wymaganych specjalnych kwalifikacji,

- zastosowanie zarzucanych lub niesprawdzonych metod i środków leczenia,

- dokonanie zbędnego zabiegu,

- pozostawienie ciał obcych w polu operacyjnym,

- dopuszczenie się błędu medycznego ${ }^{16}$,

- zastosowanie eksperymentu medycznego.

14 Raport przygotowany przez zespół kancelarii BFP kierowany przez mec. J. Budzowską opracowany na zlecenie Centrum Monitorowania Jakością w ochronie zdrowia pt. Raport $z$ badania spraw sadowych o błędy medyczne i z badania orzecznictwa Wojewódzkich Komisji do Spraw Orzekania o Zdarzeniach Medycznych, obejmujący lata 2012-2013, http://bf.com.pl/odszkodowania/poszkodowany-pacjent-sadzie-komisjaraport-badania, dostęp 20.03.2015.

${ }_{15}$ M. Nesterowicz, Prawo medyczne (wyd. X uaktualnione i poszerzone), Dom Organizatora, Toruń 2013.

16 Błąd medyczny w orzecznictwie sądowym najczęściej rozumiany jest jako czynność (zaniechanie) lekarza w zakresie diagnozy i terapii niezgodnej z nauką medyczną w zakresie dla lekarza dostępnym - Wyrok sądu najwyższego z dnia 1 kwietnia 1955 r. o sygnaturze IV CR 39/54. 
Aby zatem było możliwe dokonanie oceny danych statystycznych, należy wyjaśnić kilka kwestii dotyczących sposobu ewidencji spraw oraz zmian przepisów, jakie zaszły w 2005 r.

Ewidencja spraw w sądach powszechnych prowadzona jest ze względu na rodzaj placówki leczniczej, której dotyczy sprawa. Ze względów historycznych wyróżnia się trzy rodzaje placówek, którymi są tzw. SPZOZ-y, czyli Samodzielne Publiczne Zakłady Opieki Zdrowotnej, placówki podlegające Skarbowi Państwa i jednostkom samorządu terytorialnego oraz tzw. NZOZ-y, czyli Niepubliczne Zakłady Opieki Zdrowotnej.

Pierwsza z kategorii dotyczy tzw. SPZOZ - stosowana jest do zakładów, które były tworzone i utrzymywane przez podmioty prawa budżetowego, posiadały pełną osobowość prawną i samodzielność działania na własny rachunek, pokrywały koszty swojej działalności i zobowiązania z posiadanych środków i uzyskiwanych przychodów.

W systemie prawnym obowiązującym od $2011 \mathrm{r}$. SPZOZ są identyfikowane jako jednostki niebędące przedsiębiorcami. Są to wyodrębnione organizacyjnie zespoły osób i środków majątkowych, utworzone i utrzymywane w celu udzielania świadczeń zdrowotnych i promocji zdrowia, wyposażone w przymiot osobowości prawnej.

Drugą kategorię stanowią jednostki podlegające Skarbowi Państwa lub jednostki samorządu terytorialnego - w związku ze szkodą zaistniałą w niesamodzielnym publicznym zakładzie służby zdrowia (w tym także przed 1 stycznia 1999 r.). Kategoria ta obejmuje zatem jednostki, które posiadają tzw. ułomną osobowość prawną i które najczęściej prowadzone są $\mathrm{w}$ formie jednostki budżetowej lub zakładu budżetowego (te od 2011 r. zostały w całości zlikwidowane).

Trzecią kategorię natomiast stanowią NZOZ-y, które w myśl ustawy o zakładach opieki ${ }^{17}$ zdrowotnej stanowiły wszystkie instytucje lecznicze, które były tworzone i utrzymywane przez Kościoły i związki wyznaniowe, instytucje ubezpieczeniowe, zakłady pracy, stowarzyszenia, fundacje i inne osoby prawne lub podmioty zagraniczne. Natomiast po wejściu w życie ustawy o działalności leczniczej ewidencja sądu przyjmuje, że są to prywatne i spółdzielcze zakłady służby zdrowia, bez względu na ich formę organizacyjną.

Dla statystyki sądowej istotne znaczenie miała również zmiana, jaka zaszła w 2005 r., dotycząca kwestii podwyższenia progu wymagalności odnoszącego się do wysokości przedmiotu sporu ${ }^{18}$.

17 Ustawa z dnia 30 sierpnia o zakładach opieki zdrowotnej Dz. U. 1991, nr 91, poz. 408, z późn. zm.

18 Pierwotnie próg ten został określony w Dz. U. 2000, nr 48, poz. 554 - ustawa - Kodeks postępowania cywilnego, ustawa o zastawie rejestrowym i rejestrze zastawów, ustawy o kosztach sądowych w sprawach cywilnych oraz ustawy o komornikach sądowych i egzekucji, uległ podwyższeniu na mocy Dz. U. 2004, nr 172, poz. 1804 - Ustawa kodeks postępowania cywilnego oraz niektóre inne ustawy. W myśl art. 1, pkt 6 wspomnianej ustawy sądy okręgowe rozpatrują sprawy o prawa majątkowe, w których wartość sporu przewyższa 75 tys. PLN. 


\section{Statystyka spraw o odszkodowania za szkody wyrządzone przez służbę zdrowia}

Analizując statystykę wpływu spraw o odszkodowanie za szkody wyrządzone przez służbę zdrowia (tabela 1) można zauważyć, iż wbrew powszechnie panującym opiniom liczba prowadzonych spraw rośnie dość nieznacznie, a w porównaniu z rokiem 2002 wręcz spadła aż o ponad 500 spraw (2014 r.).

Tabela 1. Ewidencja wpływu spraw o odszkodowanie za szkody wyrządzone przez służbę zdrowia w latach 2001-2014

\begin{tabular}{|l|r|r|r|r|r|r|r|r|r|r|r|r|r|r|}
\hline Kategoria jednostki & 2001 & 2002 & 2003 & 2004 & 2005 & 2006 & 2007 & 2008 & 2009 & 2010 & 2011 & 2012 & 2013 & 2014 \\
\hline SPZOZ & 868 & 1143 & 1110 & 1006 & 883 & 824 & 690 & 647 & 656 & 663 & 678 & 800 & 801 & 774 \\
\hline $\begin{array}{l}\text { Podlegające Skarbowi } \\
\text { Państwa lub } \\
\text { jednostki samorządu } \\
\text { terytorialnego }\end{array}$ & 386 & 263 & 193 & 188 & 137 & 127 & 110 & 93 & 62 & 71 & 91 & 69 & 62 & 50 \\
\hline NZOZ & 41 & 41 & 71 & 71 & 61 & 75 & 63 & 66 & 53 & 80 & 93 & 102 & 127 & 97 \\
\hline Razem & 1295 & 1447 & 1374 & 1265 & 1081 & 1026 & 863 & 806 & 771 & 814 & 862 & 971 & 990 & 921 \\
\hline
\end{tabular}

Źródło: Opracowanie własne na podstawie danych statystycznych Ministerstwa Sprawiedliwości.

Najwięcej pozwów kierowanych jest przeciwko Samodzielnym Publicznym Zakładom Opieki Zdrowotnej. Zauważalna jest również malejąca tendencja wpływu spraw przeciwko jednostkom podlegającym Skarbowi Państwa lub jednostkom samorządu terytorialnego, natomiast w wypadku niepublicznych zakładów opieki zdrowotnej ta liczba wyraźnie wzrasta. Sytuacja ta ma związek ze zmianami struktury rynku zdrowia, jakie nastąpiły po wprowadzeniu w 1997 r. ustawy o zmianie ustawy o zakładach opieki zdrowotnej i innych ustaw ${ }^{19}$, która zobligowała wszystkie funkcjonujące do tego czasu zakłady opieki zdrowotnej do przekształcania ich w samodzielne zakłady opieki zdrowotnej oraz dopuściła do legalnego tworzenia niepublicznych zakładów opieki zdrowotnej.

Tym samym, nastąpił wyraźny rozwój ostatniej z omawianych form, który jak można zauważyć (tabela 2) zwiększył liczbę funkcjonujących na rynku prywatnym przychodni oraz szpitali. Najszybszy wzrost liczby powstających placówek widoczny jest w wypadku przychodni niepublicznych, których w 2001 r. było ok. 2200, natomiast 10 lat później już około 16 400. Obserwowany wzrost liczby placówek szpitalnych

\footnotetext{
${ }_{19}$ Ustawa z dnia 20 czerwca 1997 r. o zmianie ustawy o zakładach opieki zdrowotnej oraz o zmianie niektórych innych ustaw, Dz. U. 1997, nr 104, poz. 661 z późn. zm.
} 
również jest dynamiczny, jednak nie tak imponujący, jak przychodni. Tendencja ta nieco zaczyna się odwracać w latach 2012 i $2013^{20}$, gdy zauważalny jest nieco szybszy wzrost liczby placówek szpitalnych.

Tabela 2. Liczba przychodni i szpitali w Polsce w latach 2001-2013

\begin{tabular}{|l|r|r|r|r|r|r|r|r|r|r|r|c|c|}
\hline & 2001 & 2002 & 2003 & 2004 & 2005 & 2006 & 2007 & 2008 & 2009 & 2010 & 2011 & 2012 & 2013 \\
\hline Przychodnie & $\mathbf{5 7 7 6}$ & $\mathbf{5 6 5 7}$ & $\mathbf{1 1 9 7 8}$ & $\mathbf{1 2 1 0 1}$ & $\mathbf{1 2 2 7 3}$ & $\mathbf{1 3 4 7 3}$ & $\mathbf{1 4 2 0 6}$ & $\mathbf{1 4 8 5 3}$ & $\mathbf{1 6 2 5 2}$ & $\mathbf{1 6 6 0 8}$ & $\mathbf{1 9 1 5 1}$ & 19412 & 19529 \\
\hline Publiczne & 2201 & 1762 & 3575 & 3369 & 3258 & 3154 & 3192 & 3298 & 2967 & 2733 & 2763 & $\mathrm{x}$ & $\mathrm{x}$ \\
\hline Niepubliczne & 3575 & 3895 & 8403 & 8732 & 9015 & 10319 & 11014 & 11555 & 13285 & 13875 & 16388 & $\mathrm{x}$ & $\mathrm{x}$ \\
\hline Szpitale & $\mathbf{7 3 6}$ & $\mathbf{7 3 9}$ & $\mathbf{7 3 2}$ & $\mathbf{7 9 0}$ & $\mathbf{7 8 1}$ & $\mathbf{7 4 2}$ & $\mathbf{7 4 8}$ & $\mathbf{7 3 2}$ & $\mathbf{7 5 4}$ & $\mathbf{7 9 5}$ & $\mathbf{8 1 4}$ & $\mathbf{9 1 3}$ & $\mathbf{9 6 6}$ \\
\hline Publiczne & 691 & 678 & 660 & 644 & 611 & 589 & 578 & 546 & 526 & 509 & 501 & $\mathrm{x}$ & $\mathrm{x}$ \\
\hline Niepubliczne & 45 & 61 & 72 & 146 & 170 & 153 & 170 & 186 & 228 & 286 & 313 & $\mathrm{x}$ & $\mathrm{x}$ \\
\hline
\end{tabular}

Źródło: Opracowanie własne na podstawie danych publikowanych przez GUS.

Tabela 3. Struktura wpływu spraw do sądów rejonowych i okręgowych dotyczących odszkodowań za szkody wyrządzone przez służbę zdrowia w latach 2001-2014

\begin{tabular}{|l|r|r|r|r|r|r|c|c|c|c|c|c|c|c|}
\hline & 2001 & 2002 & 2003 & 2004 & 2005 & 2006 & 2007 & 2008 & 2009 & 2010 & 2011 & 2012 & 2013 & 2014 \\
\hline Sąd okręgowy & 872 & 1107 & 942 & 957 & 686 & 682 & 579 & 582 & 524 & 585 & 613 & 746 & 773 & 725 \\
\hline Sąd rejonowy & 423 & 340 & 432 & 308 & 395 & 344 & 284 & 224 & 247 & 229 & 249 & 225 & 217 & 196 \\
\hline Razem & 1295 & 1447 & 1374 & 1265 & 1081 & 1026 & 863 & 806 & 771 & 814 & 862 & 971 & 990 & 921 \\
\hline
\end{tabular}

Źródło: Opracowanie własne na podstawie danych statystycznych Ministerstwa Sprawiedliwości.

W wypadku struktury wpływu spraw (tabela 3) można zauważyć, iż najwięcej pozwów wpływa do sądów okręgowych. Udział spraw rozpatrywanych w tych sądach w stosunku do wszystkich spraw z zakresu szkód na pacjentach rozpatrywanych w sądach powszechnych wynosił ok. $70 \%$. W 2004 r. sięgnął on aż 76\%, a zmiana wspomnianych progów wymagalności wpłynęła na zmniejszenie tego udziału w 2005 r. do 63\%, odciążając tym samym sądy okręgowe. Patrząc jednak na dynamikę wpływu spraw w kolejnych latach, widać, że zmiana progu wymagalności wpłynęła tylko chwilowo na zmianę tej struktury, gdyż w kolejnych latach widoczny jest ponowny wzrost liczby spraw o odszkodowanie za szkodę wyrządzoną przez służbę zdrowia, jakie trafiają do sądów okręgowych, przy jednoczesnym spadku ich wpływu do sądów rejonowych. Dla podkreślenia warto wskazać, iż w 2014 r. udział spraw

${ }^{20}$ Ze względu na wprowadzenie ustawy o działalności leczniczej, która zastąpiła obowiązującą do $2012 \mathrm{r}$. ustawę o zakładach opieki zdrowotnej Główny Urząd Statystyczny przestał wyodrębniać placówki ze względu na organ tworzący, a podaje liczbę placówek ze względu na fakt posiadania przez nie kontraktu z Narodowym Funduszem Zdrowia. Zatem liczba przychodni i liczba szpitali zawiera w sobie łącznie podmioty będące przedsiębiorcami i te, które nimi nie są. 
rozpatrywanych przez sądy okręgowe w stosunku do wszystkich spraw rozpatrywanych w sądach powszechnych wyniósł aż $79 \%$.

Tabela 4. Sposób rozpatrzenia spraw o odszkodowania za szkody wyrządzone przez podmioty udzielające świadczeń zdrowotnych, prowadzonych przed sądami okręgowymi i rejonowymi łącznie w latach 2001-2014

\begin{tabular}{|l|r|r|r|r|r|r|r|r|r|r|r|r|r|r|}
\hline & 2001 & 2002 & 2003 & 2004 & 2005 & 2006 & 2007 & 2008 & 2009 & 2010 & 2011 & 2012 & 2013 & 2014 \\
\hline Załatwiono & 1774 & 1181 & 1426 & 1361 & 1394 & 1069 & 936 & 830 & 782 & 740 & 769 & 801 & 799 & 891 \\
\hline $\begin{array}{l}\text { Uwzględniono } \\
\text { powództwo }\end{array}$ & 543 & 447 & 540 & 444 & 391 & 301 & 252 & 211 & 207 & 187 & 191 & 200 & 190 & 240 \\
\hline Ugoda & 53 & 59 & 57 & 46 & 40 & 11 & 44 & 33 & 19 & 14 & 22 & 8 & 17 & 22 \\
\hline Oddalono powództwo & 255 & 215 & 317 & 345 & 363 & 329 & 273 & 259 & 264 & 229 & 107 & 129 & 295 & 283 \\
\hline $\begin{array}{l}\text { Odrzucenie lub zwrot } \\
\text { pozwu }\end{array}$ & 116 & 112 & 174 & 163 & 122 & 163 & 133 & 101 & 106 & 88 & 99 & 132 & 110 & 113 \\
\hline $\begin{array}{l}\text { Umorzenie lub inne } \\
\text { załatwienie sprawy }\end{array}$ & 807 & 348 & 338 & 363 & 478 & 265 & 234 & 226 & 186 & 222 & 350 & 332 & 187 & 233 \\
\hline
\end{tabular}

Źródło: Opracowanie własne na podstawie publikowanych statystyk przez Ministerstwo Sprawiedliwości.

Analizując natomiast sposób rozpatrzenia spraw o odszkodowanie (tabela 4), można zauważyć, że liczba załatwionych spraw w ciągu roku stopniowo spada. Coraz mniej również spraw kończy się pomyślnie dla poszkodowanych. Udział bowiem procentowy spraw rozstrzygniętych na korzyść powoda, którym był poszkodowany pacjent, poprzez uwzględnienie roszczenia w części lub całości czy też zawarcie ugody, wynosił w 2001 r. 34\%, natomiast w 2002 r. aż 43\%. W latach 2013 i 2014 odpowiednio wynosił on już tylko 26\% i 29\%. Oznacza to, że średniorocznie w latach 2001-2014 uznawano około 342 roszczenia poszkodowanych pacjentów, które wynikały z zajścia nieprawidłowości w procesie leczenia. Udział spraw podlegających oddaleniu w liczbie wszystkich załatwionych spraw waha się w zależności od roku między $14 \%$ (lata 2001 i 2011) a 37\% (rok 2013). Biorąc natomiast pod uwagę udział spraw, które zostały zakończone w wyniku odrzucenia lub zwrotu pozwu, zauważa się wahania między 7 a 14\% wszystkich zakończonych spraw. Pozostałe zaś sprawy były zakończone w inny sposób lub poprzez umorzenie.

\section{Komisje Wojewódzkie - skala problemu}

Jak wspomniano na wstępie, Komisje Wojewódzkie do spraw orzekania o zdarzeniach medycznych zostały powołane do życia ustawą o zmianie ustawy o prawach 
pacjenta i Rzeczniku Praw Pacjenta ${ }^{21}$. Stanowią one alternatywny do sądowego sposób dochodzenia roszczeń majątkowych przez pacjentów poszkodowanych w wyniku działalności leczniczej placówki o charakterze szpitalnym. Swoją działalność rozpoczęły w 2012 r. Ich głównym zadaniem jest ustalenie, czy w danej placówce szpitalnej doszło do zajścia tzw. zdarzenia medycznego, które jest definiowane jako: zakażenie pacjenta biologicznym czynnikiem chorobotwórczym, uszkodzenie ciała, rozstrój zdrowia pacjenta albo śmierć pacjenta będąca następstwem działań niezgodnych $\mathrm{z}$ aktualną wiedzą medyczną:

1) diagnozy, jeżeli spowodowała ona niewłaściwe leczenie albo opóźniła właściwe leczenie, przyczyniając się do rozwoju choroby,

2) leczenia, w tym wykonania zabiegu operacyjnego,

3) zastosowania produktu leczniczego lub wyrobu medycznego.

Aby sprawa była przez wyżej wspomniane komisje rozpatrywana, do zdarzenia medycznego musiało dojść po 1 stycznia 2012 r. Statystykę dotyczącą wpływu spraw można znaleźć w sprawozdaniach Rzecznika Praw Pacjenta za lata 2012-2013 (tabela 5).

Tabela 5. Wpływ spraw do Komisji Wojewódzkich do spraw orzekania o zajściu zdarzenia medycznego w latach 2012-2013

\begin{tabular}{|c|c|c|c|c|c|}
\hline & \multirow{2}{*}{$\frac{\text { Komisje Wojewódzkie ds. zdarzeń medycznych }}{\text { Wpływ }}$} & \multicolumn{2}{|c|}{2012} & \multicolumn{2}{|c|}{2013} \\
\hline & & 432 & & 1310 & \\
\hline & Prowadzono & 432 & & 1118 & \\
\hline \multirow{5}{*}{ 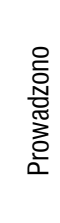 } & Zwrot & 110 & $25,46 \%$ & 214 & $19,14 \%$ \\
\hline & Rozpatrzono & 114 & & 357 & \\
\hline & Zdarzenie medyczne & 33 & $28,95 \%$ & 103 & $28,85 \%$ \\
\hline & Brak zdarzenia medycznego & 72 & $63,16 \%$ & 235 & $65,83 \%$ \\
\hline & Umorzenie & 9 & $7,89 \%$ & 19 & $5,32 \%$ \\
\hline \multicolumn{2}{|c|}{ Przeniesiono na okres następny } & 208 & & 547 & \\
\hline
\end{tabular}

Źródło: Opracowanie własne na podstawie sprawozdań dotyczących przestrzegania praw pacjenta na terytorium Rzeczypospolitej Polskiej za lata 2012, 2013 przygotowanych przez Rzecznika Praw Pacjenta.

Jak można zauważyć, analizując dane zawarte w tabeli 15, metoda dochodzenia odpowiedzialność przed Komisjami Wojewódzkimi w dość szybkim tempie zyskała zwolenników. W pierwszym bowiem okresie do Komisji Wojewódzkiej wpłynęły 432 wnioski, natomiast w 2013 r. było ich niemal trzykrotnie więcej. Jednakże na uwagę zasługuje fakt, iż dość duży odsetek wniosków stanowią zwrócone z przyczyn

21 Ustawa $z$ dnia 28 kwietnia 2011 o zmianie ustawy o prawach pacjenta i Rzeczniku Praw Pacjenta oraz ustawy o ubezpieczeniach obowiązkowych, Ubezpieczeniowym Funduszu Gwarancyjnym i Polskim Biurze Ubezpieczycieli Komunikacyjnych, Dz. U. 2011, nr 113, poz. 660. 
formalnych, takich jak: niekompletność wniosku, nieopłacenie wniosku, brak danych podmiotu leczniczego prowadzącego szpital, brak propozycji odszkodowania, zdarzenie miało miejsce przed 1 stycznia $2012 \mathrm{r}$. lub podmiot nie był szpitalem ${ }^{22}$.

\section{Podsumowanie}

Wydawać by się mogło, iż wprowadzenie nowej pozasądowej metody dochodzenia roszczeń przez poszkodowanych pacjentów wpłynie na zmniejszenie się liczby pozwów w sądach powszechnych. Niestety, patrząc na dane z tabeli 1 i 5, widzimy, iż dzieje się wręcz przeciwnie. Wraz ze wzrostem liczby wpływu wniosków do Komisji Wojewódzkich wzrasta liczba wnoszonych pozwów do sądów powszechnych. Według opinii wielu prawników zjawisko to związane jest $\mathrm{z}$ faktem, że wielu poszkodowanych pacjentów traktuje Komisje Wojewódzkie jako narzędzie do zdobycia szybkiej wiarygodnej opinii na temat zajścia zdarzenia medycznego, którą następnie wykorzystują podczas procesu sądowego.

Tezę tę potwierdza J. Budzowska w swoim raporcie. Pokazuje w nim bowiem, iż 40,82\% pacjentów przyjmuje propozycje świadczeń odszkodowawczych przyznane przez szpitale (lub ich ubezpieczycieli) po uzyskaniu pozytywnej opinii Komisji Wojewódzkiej o zajściu zdarzenia medycznego, natomiast pozostałe $59,18 \%$ pacjentów odrzuca takie propozycje, ponieważ przyjęcie proponowanego świadczenia wiąże się z zamknięciem ewentualnej drogi do dochodzenia swoich roszczeń przed sądami powszechnymi ${ }^{23}$.

Aby zatem zwiększyć wartość użytkową danych statystycznych sądów powszechnych, należałoby zacząć monitorować, ile prowadzonych w nich spraw stanowią te, które wcześniej były rozpatrywane ze skutkiem pozytywnym dla pacjenta przed Komisjami Wojewódzkimi. Informacja taka może być bowiem istotna m.in. z punktu widzenia przyszłych możliwości wprowadzania dalszych zmian w funkcjonujących reżimach odpowiedzialności, które mogłyby usprawnić proces dochodzenia swoich praw przez poszkodowanych pacjentów.

${ }^{22}$ K.B. Kozłowska, Sprawozdanie dotyczace przestrzegania praw pacjenta na terytorium Rzeczypospolitej Polskiej za rok 2012 http://www.bpp.gov.pl/gfx/bpp/userfiles/_public/bip/sprawozdania_roczne/sprawozdanie2012.pdf, dostęp 20.03.2015; K.B. Kozłowska, Sprawozdanie dotyczace przestrzegania praw pacjenta na terytorium Rzeczypospolitej Polskiej za rok 2013, http://www.bpp.gov.pl/gfx/bpp/userfiles/_public/bip/sprawozdania_roczne/cjenta_na_terytorium_rzeczypospolitej_polskiej.obejmuje_okres_od_dnia_1_stycznia_2013_r._do_dnia_31_grudnia_2013_r.1.pdf, dostęp 20.03.2015.

${ }^{23} \mathrm{~J}$. Budzowska, Raport $z$ badania spraw sadowych o błędy medyczne $i z$ badania orzecznictwa Wojewódzkich Komisji do Spraw Orzekania o Zdarzeniach Medycznych, http://bf.com.pl/odszkodowania/poszkodowany-pacjent-sadzie-komisja-raport-badania, dostęp 15.03.2015. 


\section{Bibliografia}

Budzowska J., Raport z badania spraw sądowych o błędy medyczne i z badania orzecznictwa Wojewódzkich Komisji do Spraw Orzekania o Zdarzeniach Medycznych, 2015, http:// bf.com.pl/odszkodowania/poszkodowany-pacjent-sadzie-komisja-raport-badania, dostęp 15.03.201

Dzienis P., Odpowiedzialność cywilna za szkody wyrządzone przy udzielaniu świadczeń zdrowotnych, Regulacje prawne ochrony zdrowia, red. P. Dzienis, P. Górski, WSAP, Białystok 2006.

Filar M., O odpowiedzialności lekarzy i zakładów opieki zdrowotnej w ogólności, w: M. Filar, S. Krześ, E. Marszałkowska-Krześ i P. Zaborowski, Odpowiedzialność lekarzy i zakładów opieki zdrowotnej, LexisNexis, Warszawa 2004.

Fiutak A., Odpowiedzialność cywilna lekarzy, w: A. Fiutak, T. Podleśny, M. Kozik, P. Szczerba i K. Zblewska-Wrońska, Odpowiedzialność prawna pracowników medycznych. Przepisy, Przykłady, Orzecznictwo, C.H. Beck, Warszawa 2013.

Karkowski T., Restrukturyzacja szpitali, Wolters Kluwer business, Warszawa 2012.

Kolwitz M., Polski system ochrony zdrowia - perspektywy i możliwości zastosowania systemów ochrony zdrowia innych państw unii europejskiej, „Annales Academiae Medicae Stetinesis, Roczniki Pomorskiej Akademii Medycznej w Szczecinie” 2010, nr 56.

Korytkowska D., System raportowania niepożądanych zdarzeń jako instrument zarządzania ryzykiem w jednostkach prowadzących działalność lecznicza, w: Rynek ubezpieczeń. Współczesne problemy, red. W. Sułkowska, Difin, Warszawa 2013.

Kozłowska K.B., Sprawozdanie dotyczace przestrzegania praw pacjenta na terytorium Rzeczypospolitej Polskiej za rok 2012, http://www.bpp.gov.pl/gfx/bpp/userfiles/_public/bip/sprawozdania_roczne/sprawozdanie2012.pdf, dostęp 20.03.2015.

Kozłowska K.B., Sprawozdanie dotyczace przestrzegania praw pacjenta na terytorium Rzeczypospolitej Polskiej za rok 2013, http://www.bpp.gov.pl/gfx/bpp/userfiles/_public/bip/sprawozdania_roczne/cjenta_na_terytorium_rzeczypospolitej_polskiej._obejmuje_okres_ od_dnia_1_stycznia_2013_r._do_dnia_31_grudnia_2013_r.1.pdf, dostęp 20.03.2015.

Młynarski T., Zadośćuczynienie pieniężne za doznaną krzywdę jako świadczenie o charakterze jednorazowym, „Monitor Ubezpieczeniowy” 2012, nr 51.

Nesterowicz M., Prawo medyczne, wyd. X (uaktualnione i poszerzone), Dom Organizatora, Toruń 2013.

Nowakowski L., Ubezpieczenia odpowiedzialności cywilnej, Poltex, Warszawa 2004.

Ostrowski S., Mikos, M., System raportowania zdarzeń niepożądanych - model lubelski, „Ogólnopolski Przegląd Medyczny” 2007, nr 5.

Paszkowska M., Zarządzanie podmiotami leczniczymi, Aspekty prawne, Wydawnictwo AMELIA Aneta Siewiorek, Rzeszów 2014. 
Rudawska I., Opieka zdrowotna - aspekty rynkowe i marketingowe, PWE, Warszawa 2007.

Szczerba P., Odpowiedzialnośc karna lekarzy, w: A. Fiutak, T. Podleśny, M. Kozik, P. Szczerba, K. Zblewska-Wrońska, Odpowiedzialność prawna pracowników medycznych. Przepisy, Przykłady, Orzecznictwo, C.H. Beck, Warszawa 2013.

Ustawa o działalności leczniczej, Dz. U. 2011, nr 112, poz. 654 z późn. zm.

Ustawa o zmianie ustawy o prawach pacjenta i Rzeczniku Praw Pacjenta oraz ustawy o ubezpieczeniach obowiązkowych, Ubezpieczeniowym Funduszu Gwarancyjnym i Polskim Biurze Ubezpieczycieli Komunikacyjnych, Dz. U. 2011, nr 113, poz. 660.

Ustawa z dnia 20 czerwca 1997 r. o zmianie ustawy o zakładach opieki zdrowotnej oraz o zmianie niektórych innych ustaw, Dz. U. 1997, nr 104, poz. 661 z późn. zm.

Ustawa z dnia 30 sierpnia o zakładach opieki zdrowotnej, Dz. U. 1991, nr 9, poz. 408.

\section{Statistical Records of Cases of Compensation for Civil Liability Medical (Therapeutic) Entities in Litigation Poland}

The article analyses damage claims for medical malpractice in Poland. The article describes types of responsibility for medical malpractice. Although available data have been analyzed, the evidence suggests that official statistical data underestimates the number of claims. The reason for such underestimation lays with existing barriers that discourage patients from claiming the damages. Even though new methods of claiming damages were introduced, the barriers remain in place. Therefore the author proposes introduction of monitoring of cases held in courts in order to improve the value of statistical data which would lead to more efficient investigation of medical malpractice claims by the existing Voivodeship Committees.

Keywords: healthcare entity, healthcare institution, civil liability, medical event

\section{Le registre statistique des poursuites pour dommages-intérêts au titre de la responsabilité civile des unités de soins en Pologne}

L'article présente les revendications des patients pour les dommages causés par des unités de santé en Pologne. L'auteur décrit les régimes de responsabilité qui régissent ces entités et analyse les données statistiques disponibles sur ce sujet. Les résultats de l'analyse suggèrent que les données statistiques officielles 
sous-estiment le nombre de demandes d'indemnisation. Parmi les raisons de cette sous-estimation sont les obstacles existants qui découragent les patients. Même si de nouvelles méthodes permettant de demander des dommages-intérêts ont été introduites, les obstacles demeurent. Par conséquent, l'auteur propose l'introduction de la surveillance des cas tenus dans les tribunaux afin d'améliorer la qualité des données statistiques, ce qui pourrait conduire à une enquête plus efficace des demandes par les Comités dans les voïvodies en Pologne.

Mots-clés: les unités de soins, les unités de santé, la responsabilité civile, les événements médicaux

\section{Статистические данные в Польше, касающиеся медицинской халатности и исков по делам о возмещении вреда, причиненного здоровью}

Статья относится к искам по делам об ущербе, причиненном пациенту субъектами здравоохранения. Представляется режим ответственности этих организаций и проводится анализ имеющихся данных по этой теме. Результаты исследования показывают, что статистические данные не отражают реальных масштабов потенциальных заявлений, сделанных жертвами, из-за барьеров, препятствующих жертвам заявить свои претензии. Введение нового метода отстаивания своих прав пациентами в воеводском комитете, не оказало существенного влияния на подаваемые иски. Поэтому автор предлагает ввести мониторинг дел в судах для повышения ценности статистических данных. Мониторинг должен привести к более эффективному исследованию дел о возмещении вреда, причиненного здоровью.

Ключевые слова: предприятия сферы здравоохранения, учреждения здравоохранения, гражданская ответственность, медицинское происшествие 
